\title{
First species of Ephistemus (Coleoptera: Clavicornia: Cryptophagidae) from Baltic amber
}

\section{Первый вид рода Ephistemus (Coleoptera: Clavicornia: Cryptophagidae) из балтийского янтаря}

\author{
G.Yu. Lyubarsky', E.E. Perkovsky ${ }^{2,3}$

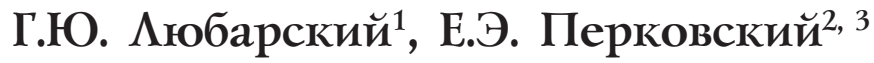

\footnotetext{
${ }^{1}$ Zoological Museum, Moscow Lomonosov State University, Bol'shya Nikitskaya 2, Moscow 125009, Russia. E-mail: lgeorgy@rambler.ru

${ }^{2}$ Schmalhausen Institute of Zoology, National Academy of Sciences of Ukraine, Bogdan Khmielnitsky str. 15, Kiev 01601, Ukraine. E-mail: perkovsk@gmail.com

${ }^{3}$ Borissiak Paleontological Institute, Russian Academy of Sciences, Profsoyuznaya str. 123, Moscow 117997, Russia.

1 Зоологический музей, Московский государственный университет им. М.В. Ломоносова, Большая Никитская ул. 2, Москва 125009 , Россия.

${ }^{2}$ Институт зоологии им. И.И. Шмальгаузена, Киев, Украина.

${ }^{3}$ Палеонтологический институт им. А.А. Борисяка РАН, Профсоюзная ул. 123, Москва 117997, Россия.
}

KEYWORDS. Cryptophagidae, Ephistemus, Late Eocene, Baltic amber.

КЛЮЧЕВЫЕ СЛОВА. Cryptophagidae, Ephistemus, поздний эоцен, балтийский янтарь.

ABSTRACT. Ephistemus crassipes Lyubarsky et Perkovsky sp.n., a new cryptophagid species from Baltic amber is described. This species is the first fossil representative of the genus, and the fourth described species of Eocene Atomariinae. The new species differs from extant species by thickened legs.

РЕЗЮМЕ. Описан новый вид криптофагид из балтийского янтаря - Ephistemus crassipes Lyubarsky et Perkovsky sp.n. Это четвёртый описанный эоценовый представитель Atomariinae и первый описанный ископаемый представитель рода. Новый вид отличается от современных Ephistemus утолщёнными ногами.

\section{Introduction}

A study of the collection of Christel and Hans Werner Hoffeins $(\mathrm{CCHH})$ revealed a new species of Cryptophagidae. Cryptophagidae are mainly free-living and mycophagous. The family Cryptophagidae contains two subfamilies: Cryptophaginae and Atomariinae [Leschen, 1996]. The subfamily Atomariinae contains three tribes: Atomariini, Cryptafricini and Hypocoprini. The subfamily can be diagnosed by short body, frons without tubercle, and short prosternum in front of coxa.

The specimen has 11-jointed antenna with 3-jointed club; tarsal formula 5-5-5; epipleuron incomplete; punctuation of elytra confused, without elytral striae; $1^{\text {st }}$ ventrite longer than others. This specimen is a member of Cryptophagidae, belongs to the genus Ephistemus Stephens, 1829, and has the following characters: short rounded body, antennae embedded in the grooves on the prothorax, projection of the prothorax with parallel lines along the edges. This genus belongs to the tribe Atomariini. The tribe Atomariini contains 10 genera.

Publications about any species of Ephistemus and closely related genera are rather few. The group of genera including Ephistemus, the former tribe of Ephistemini, is poorly studied. The Palaearctic species of the closely related genus Curelius Casey, 1900 were keyed by Johnson [1971]. Information on the species list has not been updated for a long time. Recently, Esser [2017] published a work describing a new species of the related genus Curelius from the Afrotropical Region and new findings of Ephistemus. E. globulus (Paykull, 1798) has been found at damp moist points in the forest as well as on dead fungi and has been sieved from dry fern.

Six extant Ephistemus species are widely distributed [Leschen, 1996]. Of the three Palaearctic species [Johnson et al., 2007] only E. reitteri Casey, 1900 is unknown from other realms: E. globulus is known from Palaearctic, Nearctic, and New Zealand and E. splendens Johnson, 1971 from Palaearctic and Oriental regions. Recent Ephistemus beetles feed on fungal spores and hyphae, living in rotting vegetation, mammal dung and nests.

The genus is rarely recorded in the Late Eocene ambers. The first Baltic amber species was indicated some years ago [Kubisz, 2000], but the species was not

How to cite this article: Lyubarsky G.Yu., Perkovsky E.E. 2019. First species of Ephistemus (Coleoptera: Clavicornia: Cryptophagidae) from Baltic amber // Russian Entomol. J. Vol.28. No.1. P.54-57. doi: 10.15298/ rusentj.28.1.07 
described. In the present paper we describe a new species of Ephistemus from Baltic amber, the first named representative of the genus from Eocene amber. Earlier we described three species of Atomaria from Eocene ambers [Lyubarsky, Perkovsky, 2013; Perkovsky, Lyubarsky, 2014; Lyubarsky, Perkovsky, 2018]. The spe-

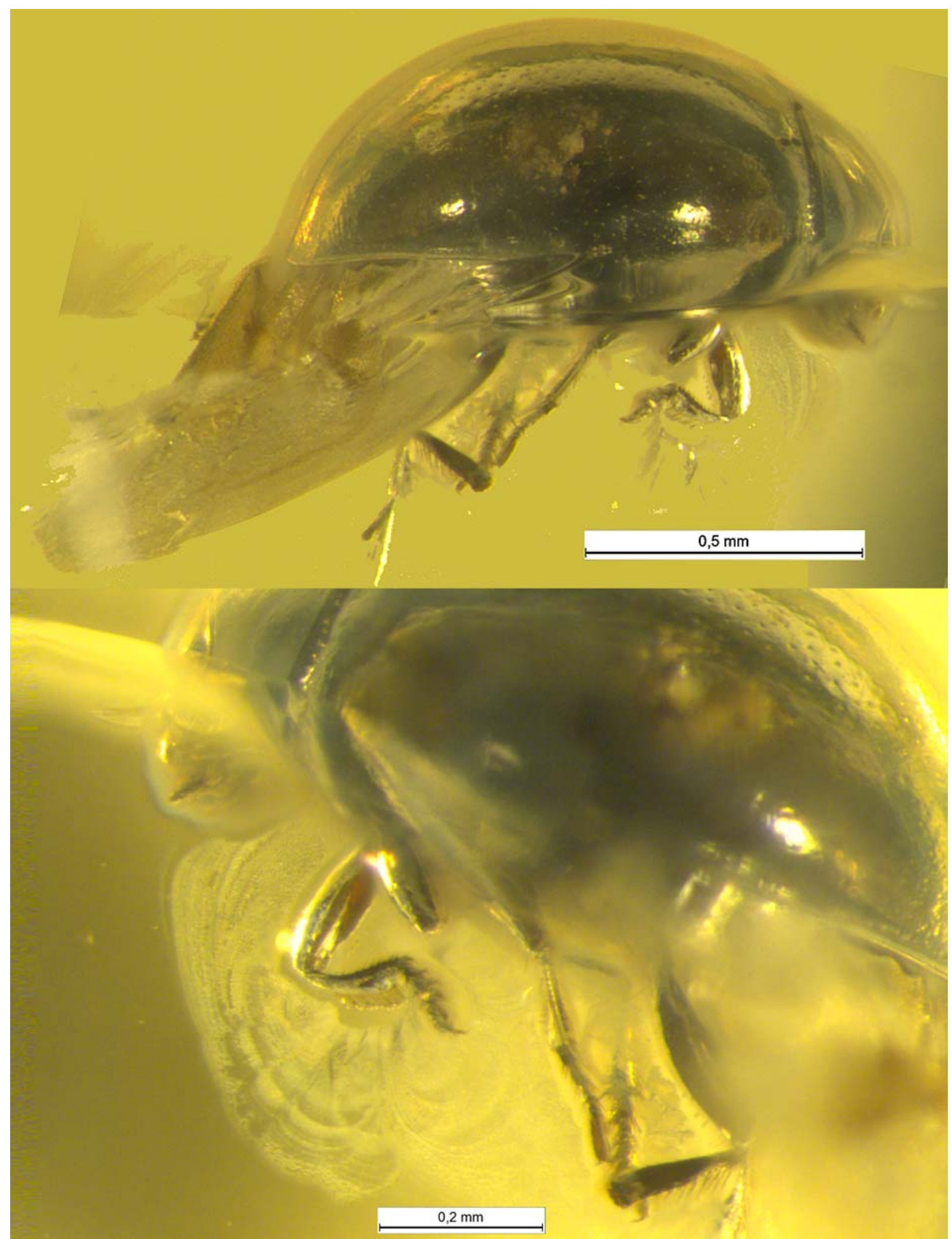

Figs 1-2. Ephistemus crassipes sp.n.: 1 - lateral view; 2 - structure of tarsi. Pис. 1-2. Ephistemus crassipes sp.n.: 1 - сбоку; 2 - строение лапок. 
cies of the genus Ephistemus is the fourth species of subfamily Atomariinae from Eocene ambers.

Photographs were taken at the Schmalhausen Institute of Zoology (Kiev, SIZK) using the microscope Leica MZ 16.

\section{Taxonomy}

Family Cryptophagidae Kirby, 1826

Subfamily Atomariinae LeConte, 1861

Genus Ephistemus Stephens, 1829

\section{Ephistemus crassipes Lyubarsky et Perkovsky, sp.n. Figs $1-3$.}

MATERIAL. Holotype: 1223-2, in collection of Christel and Hans Werner Hoffeins (Hamburg), Yantarnyi, Baltic amber, Late Eocene. The type will be deposited at the amber collection of Senckenberg Deutsches Entomologisches Institut Müncheberg (SDEI), Germany. Collection code: CCHH.

DESCRIPTION. Length of body $1.2 \mathrm{~mm}$, body round, convex (Fig.1), covered with very minute sparse punctures and bearing small and very fine decumbent hair. Body, legs and antennae entirely dark brown.

Head transverse, finely punctured, distance between punctures more than diameter of puncture; with hemispherical facetted eyes; length of eye 4 times less than width of head. Eye prominent, normally developed, one eye smaller than the distance between the eyes. Head not constricted behind eye. Antennae slender, with club reaching beyond base of pronotum, joints of flagellum elongate, about 1.5 times as long as broad, antennomere 1 elongated, slightly curved, a little longer than $2^{\text {nd }}$, antennomere 3 up to over 2.5 times the length of 4 . Antennomeres $4-8^{\text {th }}$ short, 1.5 times as long as broad, $9^{\text {th }}$ slightly transverse, narrower than $10^{\text {th }}, 10^{\text {th }}$ transverse, $11^{\text {th }}$ obliquely oval, joints $9-11$ asymmetrical, equal in width, antennomere $11^{\text {th }}$ longer than $10^{\text {th }}$, slightly compressed. Antennal insertions widely separated basally. Antennal grooves on head and prosternum present. Frontoclypeal suture present.

Pronotum strongly transverse, 4 times as broad as long, weakly and finely punctured, distance between punctures equal to 4 their diameters. Anterior edge not sinuate, anterior angles without thickening or callosity. Pronotal sides converging anteriorly, greatest width at base. Base of the pronotum without depression in the middle; basal pits absent, hind angles rectangular; pronotal disk convex. Basal margin slightly lobed. Prosternum without punctation. Prosternal process with parallel lines. Width of mesosternal process greater than mesocoxa. Metasternum rarely punctured. On all the legs, the femur and tibia are approximately equal in length to each other. The foretarsus approximately half the length of the foretibia (Fig. 2), the metatarsus approximately two-thirds the length of the metatibia. The anterior femora thickened, approximately equal to the width of the epimeron at the base, the foretibia thickened, only slightly narrower than the femur. The tibia at the apex about twice as thick as the base. The tarsi wide, their width about half the maximal width of the tibia. Tarsomeres with fairly large lobes. Tarsal formula 5-5-5. Tibia without spurs. Longitudinal metasternal line absent. Meta-intercoxal process wider than long. Femoral line absent. Ventrite 5 evenly arcuate; ventrite 5 without crenulations, surface unmodified.

Scutellum small, pentagonal, transverse. Elytra shortoval, moderately convex, humeral corners rounded, weakly

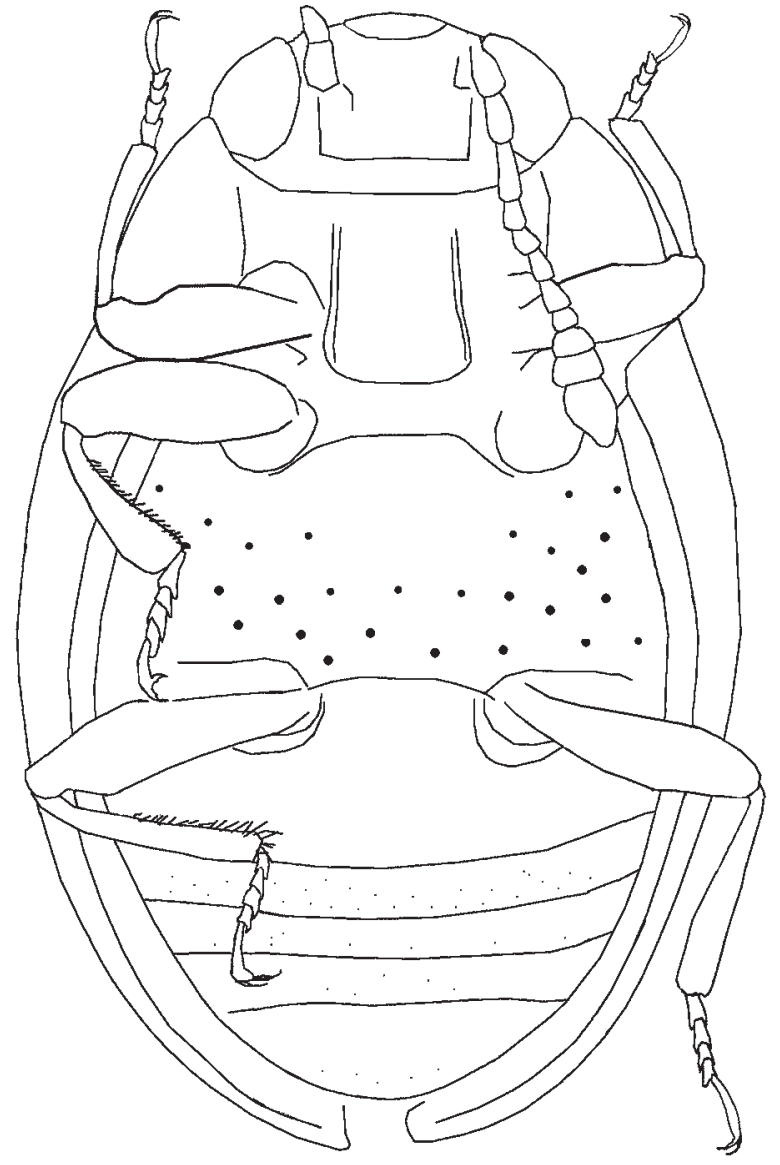

Fig. 3. Drawing of ventral view of E. crassipes sp.n.

Рис. 3. Вид снизу E. crassipes sp.n. (рисунок).

curved at sides, maximum breadth of elytra in first third of their length, 3 times as long as pronotum, 1.4 times as long as broad. Surface shining, densely punctured, punctures in basal part slightly stronger than on pronotal disk, and approximately 4 diameters apart their lateral neighbors on an average. Elytral impression absent. Epipleuron present to level of posterior margin of metasternum. Wings fully developed.

ETYMOLOGY. The species is named crassipes, because in contrast to other members of the genus, it has thick femora and tibia.

REMARKS. This species differs from other members of the genus Ephistemus by thickened femur and tibia.

The genus is known from Holarctic, Oriental region and Central America, circumtropical. Ephistemus apicalis LeConte, 1863 distributed in USA; E. distans Sharp, 1900, in Guatemala; E. globulus (Paykull, 1798), in Algeria, Italy, Germany, Norway, Russia, Georgia, Iran, China, USA, New Zealand; E. perminutus Casey, 1924, in USA; E. reitteri Casey, 1900, in United Kingdom, France, Spain, Portugal, Italy, Greece, Germany, Switzerland, Austria, Czechia, Hungary, Poland, Bulgaria, Russia, Azerbaijan, Iran, Turkey, Israel; E. splendens Johnson, 1971, in Pakistan, India, Nepal, China.

Other species of the genus are usually distinguished by the elytral punctation and the size of the body, color and shagreening of elytra, the relative width of the segments of antennal club. For example, E. splendens differs by very large and sparse punctation of pronotum and elytra. E. exiguus 
differs from the new species by a much more transverse antennal club. The new species differs primarily in the structure of the legs. It has wider femur and tibia than other species of the genus. The tarsi are somewhat longer and thicker than those of recent species. The new species does not differ in the punctation of elytra. For example, itdoes not differ from E. globulus, punctured rarely and weakly, much weaker than E. splendens. In E.globulus, the hind tarsi are slightly thickened, with small pubescent lobes. Unlike E. reitteri, the new species does not have shagreened elytra (and has thicker legs).

The climate of the southern coast of Subparathetys was much warmer than that of the Baltic amber forest [Wolfe et al., 2016; Mänd et al., 2018; Sokoloff et al., 2018; Perkovsky, Olmi, 2018; Perkovsky, 2018], which determined a much higher share of the tropical elements in the fauna [Perkovsky, 2013, 2016, 2017]. Some tropical elements from Bitterfeld and Rovno amber, e.g. Thallisellini (Erotylidae: Languriinae), the Litochropus genus group (Phalacridae) [Lyubarsky, Perkovsky, 2016, 2017a], Valenfriesiini (Anthribidae) [Legalov et al., 2018] are unknown from Baltic amber, others are represented by single specimen, e.g. Corethrellidae [Baranov et al., 2016]. In the same time Holarctic and cosmopolitan taxa strongly prevail in Baltic amber [Perkovsky, 2016, 2017]; interesting, that all Late Cretaceous atomariines are known from colder Baeomorpha realm [Lyubarsky, Perkovsky, 2014, 2015, 2017b; Gumovsky et al., 2018]. It will be important to study the connections between these and Late Eocene European atomariines.

Acknowledgements. We are grateful to Christel and Hans Werner Hoffeins (Hamburg, Germany) for providing the material, to Vitaly Yu. Nazarenko (Schmalhausen Institute of Zoology, Kiev, Ukraine) for kindly taking photographs of the specimen, Alexandr P. Rasnitsyn (Borissiak Paleontological Institute, Moscow, Russia) for discussion. The work of the first author has been supported by the grant AAAA-A16-116021660077-3.

\section{References}

Baranov V.A., Kvifte G.M., Perkovsky E.E. 2016. Two new species of fossil Corethrella Coquillett from Late Eocene Rovno amber, with a species-level phylogeny for the family based on morphological traits (Diptera: Corethrellidae) // Systematic Entomology. Vol.41. No.3. P.531-540.

Esser J. 2017. On Curelius Casey, 1900 and Ephistemus Stephens, 1829 (Coleoptera, Cryptophagidae) from the Afrotropical Region // Linzer biol. Beitr. Vol.49. No.2. P.1139-1145.

Gumovsky A., Perkovsky E., Rasnitsyn A. 2018. Laurasian ancestors and "Gondwanan" descendants of Rotoitidae (Hymenoptera: Chalcidoidea): What a review of Late Cretaceous Baeomorpha revealed // Cretaceous Research. Vol.84. P.286-322. https:// doi.org/10.1016/j.cretres.2017.10.027.

Johnson C. 1971. Forgotten genus Curelius Casey in relation to Ephistemus Stephens with keys to the palaearctic species (Coleoptera, Cryptophagidae) // Entomologische Blatter. Vol.66 No.3. P. $159-162$.

Johnson C., Otero J.C., Leschen R.A.B. 2007. Family Cryptophagidae. A catalogue of Palaearctic Coleoptera vol.4 / Eds. I. Löbl, A. Smetana. Steenstrup: Apollo Books. P.513-531.

Kubisz D. Fossil beetles (Coleoptera) from Baltic amber in the collection of the Museum of Natural History of ISEA in Krakow // Polish Journal of Entomology. 2000. Vol.69. P.225-230.
Legalov A.A., Nazarenko V.Y., Perkovsky E.E. 2018. A new genus of fungus weevils (Coleoptera: Anthribidae) in Rovno amber // Foss. Rec. Vol.21. P.207-212. https://doi.org/10.5194/fr-21207-2018.

Leschen R.A.B. 1996. Phylogeny and revision of the genera of Crypophagidae (Coleoptera: Cucujoidea) // The University of Kansas. Science Bulletin. Vol.55. No.15. P.549-634.

Lyubarsky G.Yu., Perkovsky E.E. 2013. Fourth contribution on late Eocene amber silken fungus beetles: a new Baltic amber species of Atomaria (Coleoptera, Clavicornia, Cryptophagidae) // Vestnik zoologii. Vol.47. No.3. P.273-276.

Lyubarsky G.Yu., Perkovsky E.E. 2014. New species of the genus Nganasania from Upper Cretaceous of Taymyr (Coleoptera, Cryptophagidae) // Russian Entomological Journal. Vol.23. No.3. P.191-194

Lyubarsky G.Yu., Perkovsky E.E. 2015. New genus Microticus from Upper Cretaceous of Taymyr (Coleoptera: Cryptophagidae), oldest silken fungus beetle with sexually dimorphic tarsal formula // Russian Entomological Journal. Vol.24. No.1. P.61-66.

Lyubarsky G.Yu., Perkovsky E.E. 2016. A new genus, Neolitochropus (Coleoptera: Cucujoidea: Phalacridae), from the Upper Eocene Bitterfeld amber // Russian Entomological Journal. Vol.25. No.3. P.249-253.

Lyubarsky G.Yu., Perkovsky E.E. 2017a. Serramorphus, a new genus of Erotylidae from Eocene amber (Coleoptera: Clavicornia) from Late Eocene Bitterfeldian Amber // Russian Entomological Journal. Vol.26. No.1. P.37-40.

Lyubarsky G.Yu., Perkovsky E.E. 2017b. Re-description of the genus Nganasania Zherikhin from Upper Cretaceous of Taimyr (Coleoptera: Cryptophagidae) // Russian Entomological Journal. Vol.26. No.3. P.251-255.

Lyubarsky G.Yu., Perkovsky E.E. 2018. First species of Atomaria (Coleoptera: Clavicornia: Cryptophagidae) from Bitterfeld amber and several notes on Miocene and Cretaceous Cryptophagidae // Russian Entomological Journal. Vol.27. No.4. P.381385.

Mänd K., Muehlenbachs K., McKellar R.C., Wolfe A.P., Konhauser K. 2018. Distinct origins for Rovno and Baltic ambers: Evidence from carbon and hydrogen stable isotopes // Palaeogeogr. Palaeocl. V.505. P.265-273. https://doi.org/10.1016/ j.palaeo.2018.06.004.

Perkovsky E.E. 2013. Eohelea sinuosa (Meunier, 1904) (Diptera, Ceratopogonidae) in Late Eocene ambers of Europe // Paleontol. J. Vol.47. No.5. P.503-512. https://doi.org/10.1134/ S0031030113040163.

Perkovsky E.E. 2016. Tropical and Holarctic ants in Late Eocene ambers // Vestnik zoologii. Vol.50. No.2. P.111-122.

Perkovsky E.E. 2017. Comparison of biting midges of the Early Eocene Cambay amber (India) and Late Eocene European Ambers supports the independent origin of European ambers // Vestnik zoologii. Vol.51. No.6. P.275-284

Perkovsky E.E., 2018. Only a half of species of Hymenoptera in Rovno amber is common with Baltic amber // Vestnik zoologii. Vol.52. No.5. P.353-360.

Perkovsky E.E., Lyubarsky G.Yu. 2014. Fifth contribution on silken fungus beetles from Late Eocene amber: a second Baltic amber species of Atomaria (Coleoptera: Clavicornia: Cryptophagidae) // Russian Entomological Journal. Vol.23. No.1. P.41-44.

Perkovsky E.E., Olmi M. 2018. Discovery of the first pincer wasp (Hymenoptera, Dryinidae) in Rovno amber // Zootaxa. Vol.4457 No.2. P.296-304. https://doi.org/10.11646/zootaxa.4457.2.5.

Sokoloff D.D., Ignatov M.S., Remizowa M.V., Nuraliev M.S., Blagoderov V., Garbout A., Perkovsky E. E.: A male flower of Prunus s.1. (Rosaceae) from Eocene Rovno amber (Ukraine) // J. Plant Res. Vol.131. No.6. P.925-943 https://doi.org/10.1007/ s10265-018-1057-2, 2018.

Wolfe A.P., McKellar R.C., Tappert R., Sodhi R.N.S., Muehlenbachs K. 2016. Bitterfeld amber is not Baltic amber: Three geochemical tests and further constraints on the botanical affinities of succinite // Rev. Palaeobot. Palynol. Vol.225. P.21-32. 